\title{
Quality and Nutritive Value of Faba Bean (Vicia faba L.) as Affected by Production Environment and Genotype
}

\author{
Amna A. Abdalla ${ }^{1}$, Ahmed M. El Naim ${ }^{2,}$, , Musa B. Taha ${ }^{1}$ \\ ${ }^{1}$ Agricultural Research Corporation, P. O. Box 126 Wad Medani, Sudan \\ ${ }^{2}$ Department of Crop Sciences, Faculty of Natural Resources and Environmental Studies, University of Kordofan, Elobeid, Sudan \\ *Corresponding author: naim17amn@yahoo.com
}

Received November 17, 2018; Revised December 21, 2018; Accepted January 22, 2019

\begin{abstract}
Faba beans (Vicia faba L.) represent an essential source of food protein for many people in Sudan, especially those who cannot afford to buy animal meat. The demand for faba bean seeds is greatly increased in recent years, and consequently its production area was extended where the climate is marginally suitable, these marginal environments' were affect the quality aspects of faba bean. An experiment was conducted for three consecutive seasons (2005/2006, 2006/2007 and 2007/2008), at five environments representing different soil types. The objective was to study the effect of these environments on cookability (quality) of Faba bean with consideration to the prevailing temperature and relative humidity of these environments. The environments were: $\left(\mathrm{E}_{1}\right)$ : Al Salama location to represent lower terrace soil (Riverian); $\left(\mathrm{E}_{2}\right)$ : Hudeiba Research Station Farm to represent middle terrace soil (Kuru); $\left(\mathrm{E}_{3}\right)$ : Almatara location; to represent high terrace soil; $\left(\mathrm{E}_{4}\right)$ : Wad Medani location= Gazira Research Station Farm to represent central clay plain soil (Vertisols); $\left(\mathrm{E}_{5}\right)$ : Ed Damer Food Security Scheme location to present high terrace soil. Six Faba bean lines were selected: Small-medium seeded (H.72/7/1, Daba.1/1, Z B F.1/1, C.86, Triple White and Large seeded Turki. The experiment was arranged in a randomized complete block design with three replications. The results showed that soil types had significant effects on cookability aspect. The high cookability seed of faba bean under all production environments was recorded from lower terrace soil (Riverian) in $E_{1}$ (Al Salama location) and the poor cookability seeds of faba bean were recorded from the high terrace soils in $E_{3}$ (Almatara location) and $\mathrm{E}_{5}$ (Ed Damer) Food Security Scheme). The new production area $\mathrm{E}_{4}$ (Wad Medani) location) produced a moderate cookability seed.
\end{abstract}

Keywords: broad bean, seed quality, nutritive value

Cite This Article: Amna A. Abdalla, Ahmed M. El Naim, and Musa B. Taha, "Quality and Nutritive Value of Faba Bean (Vicia faba L.) as Affected by Production Environment and Genotype." World Journal of Agricultural Research, vol. 7, no. 1 (2019): 21-24. doi: 10.12691/wjar-7-1-4.

\section{Introduction}

Faba bean is the most important food legume in the Sudan. It is the main staple food and the main source of protein for millions of people. Its nutritional importance is even greater as many people have limited access to animal food protein [1]. Worldwide, faba bean is important crop ranking fourth in grain pulses after dry beans, dry peas and chickpeas [2] and is the second popular food legume in Europe [3]. The pulses world production in 2010 was 67.713 million tons in an area of 76.003 million hectares and yield of 0.9 ton/ha. However, in Sudan the production in the same year was 318 thousand tons in an area of 3.9 million hectares and yield of 0.8 ton/ha [4]. In recent years, higher meat prices coupled with the need for protein rich foods have led people in the less developed countries to shift their consumption behaviour to certain grain legumes, especially Vicia faba [5]. Faba beans, like other beans, are good source of calories, protein, carbohydrates, and fiber. They are also rich in phosphorus, iron, potassium, and vitamin B complex [6,7]. However, the ratio of calcium to phosphorus is low, so the calcium may not be well utilized unless other calcium rich foods and lower in phosphorus (such as dairy products and green leafy vegetables) are consumed in addition to the beans. The percentage of solids in the mature seeds is over three times that of the solids in the immature seeds; hence, the mature seeds are much higher in calories, protein, minerals, and starch: though the immature seeds are -a much better source of vitamins A and C. In Sudan, the crop is grown mainly under irrigation in an area of about 102381 ha, mainly in the Northern parts of the Sudan where the environmental conditions suit its production better than in other parts of the country. Small amounts of seeds are also produced in Khartoum State, Central Sudan and Jebel Marra area in Western Sudan [8]. The demand for faba bean seeds is greatly increased in recent years, and consequently its production area was extended where the climate is marginally suitable, these marginal environments' were affect the quality aspects of faba bean. A few and scattered research efforts were carried to understand the actual factors underlining the poor quality of faba bean. 
Therefore, the main objective of this study is to investigate the effect of environments and genotype on cookability of Faba bean and study the effect of pod position on faba bean cookability.

\section{Materials and Methods}

A field experiment was conducted for three seasons (2005/2006, 2006/2007 and 2007/2008), at five environments to study the effect of these environments on cookability of Faba bean (Vicia faba L.). The environments were mainly selected to represent different soil types with especial consideration to temperature and relative humidity during the growing seasons. The environments were: Environment $1\left(E_{1}\right)$ : Al Salama location it is an island nearby Atbara city (17 kilometers ), longitude $33^{\circ} 99^{\prime} \mathrm{E}$, latitude $17^{\circ} 84^{\prime}$ $\mathrm{N}$ and altitude $348 \mathrm{~m}$ above sea level to represent the lower terrace soil (Riverian). Environment $2\left(\mathrm{E}_{2}\right)$ : Hudeiba Research Station (six kilometers from Ed-Damer city), longitude $33^{\circ} 92^{`} \mathrm{E}$, latitude $17^{\circ} 56^{`} \mathrm{~N}$ and altitude $350 \mathrm{~m}$ above sea level to represent the middle terrace soil (Karu). Environment $3\left(\mathrm{E}_{3}\right)$ : Almatara location 1.5 kilometers (East) from Hudieba Research Station (Matara means: the farm that irrigated from underground water using pump), longitude $33^{\circ} 95^{`} \mathrm{E}$, latitude $17^{\circ} 56^{`} \mathrm{~N}$ and altitude $351 \mathrm{~m}$ above sea level to represent the high terrace soil. Environment $4\left(\mathrm{E}_{4}\right)$ : Wad Medani location of the Gezira Research Station Farm, longitude $33^{\circ} 29^{\circ}$ E, latitude $14^{\circ}$ $24^{\prime} \mathrm{N}$ and altitude $410 \mathrm{~m}$ above sea level to represent the central clay plain soil (Vertisols). Environment $5\left(\mathrm{E}_{5}\right)$ : Ed Damer Food Security Scheme location 4 kilometers (East) from Hudieba Research Station, longitude $33^{\circ} 97^{`}$ E, latitude $17^{\circ} 54^{\wedge} \mathrm{N}$ and altitude $355 \mathrm{~m}$ above sea level to present the high terrace soil (this environment was added in the second and third seasons to study another location of the high terrace soil). The some physical properties of study soils are shown in Table 1. Six faba bean lines were selected: the small-medium seeded H.72/7/1, Daba.1/1, Z B F.1/1, C.86, Triple White and large seeded Turki. The experiment was arranged in a randomized complete block design with three replications in the three seasons. The land was pre-irrigated, disc ploughed, harrowed and ridged to $60 \mathrm{~cm}$ apart and spaced to $10 \mathrm{~cm}$ between plants in all the seasons. The size of each plot was $6 \times 3.6$ meters consisting of six ridges. Sowing was manually done on the shoulder of the ridges on the first half of November in the River Nile locations and on the first week of December at Wad Medani location. The lines were planted at a rate of $3-4$ seeds per hole, thinned to two plants at three weeks from emergence to cater for the recommended plant population of (33 plants $/ \mathrm{m}^{2}$ ). Weeds were manually controlled for three times and irrigated was applied at $8-10$ days intervals.

At harvest, three samples of pods were collected according to their position; these were:

Lower node pods: collected from the first and the second lowest podding nodes from the soil.

Upper node pods: collected from the three upper podding nodes.

These pods (from lower and upper nodes) were kept in paper pages till drying and then threshed

Pods from the net area. This sample was to represent, all pod positions (lower, upper and central) and was randomly collected from the seeds of the net area (after drying, threshing and weighing).

The samples were sent to the laboratory of the Food Research Centre to measure the cookability (\%). Cookability test is an indicator of bean quality and nutritional value. Twenty grams of beans were processed in $200 \mathrm{~mL}$ of tap water in a Labconcoapparatus at $110^{\circ} \mathrm{C}$ for $30 \mathrm{~min}$. The sample was reweighed after processing. Cookability was calculated as follows (Elsheikh and Elzidany 1997) [9]:

$$
\text { Cookability }(\%)=\frac{\left[\begin{array}{l}
\text { weight of seeds after processing } \\
- \text { initial weight }(20 \mathrm{~g})
\end{array}\right]}{\text { initial weight }(20 \mathrm{~g})} \times 100 \text {. }
$$

The data were statistically analyzed using IRRSTAT software package.

Table 1. Physical properties of the study soils

\begin{tabular}{|c|c|c|c|c|c|c|}
\hline \multirow{2}{*}{$\begin{array}{l}\text { Environment } \\
\text { (soil type) }\end{array}$} & \multicolumn{4}{|c|}{ Mechanical Analysis } & \multirow[t]{2}{*}{ Saturation $\%$} & \multirow[t]{2}{*}{ Texture } \\
\hline & $\mathrm{CS}$ & FS & SI & Clay & & \\
\hline$E_{1}$ & 1 & 1 & 47 & 51 & 74 & Silty Clay \\
\hline $\mathrm{E}_{2}$ & 4 & 3 & 38 & 56 & 72 & Clay \\
\hline $\mathrm{E}_{3}$ & 22 & 22 & 15 & 41 & 56 & Sandy Clay \\
\hline $\mathrm{E}_{4}$ & 8 & 6 & 32 & 55 & 77 & Clay \\
\hline$E_{5}$ & 36 & 13 & 21 & 30 & 56 & Sandy Clay \\
\hline
\end{tabular}

\section{Results and Discussion}

The present study indicated that, the mean cookability (percentage) was significantly affected by faba bean environments. The result showed that $\mathrm{E}_{1}$ (Al Salama location) recorded the highest cookability $\%$ in the three seasons, while $\mathrm{E}_{3}$ (Almatara location) and $\mathrm{E}_{5}$ (El Damer food security scheme location) showed the lowest cookability in all the seasons (Table 2, Table 3). These results may be relate to the soil characteristics as; Al Salama location represent the lower terrace soil while, Almtara and El Damer food security scheme locations represent the high terrace soil which of low fertility soil. This interpretation was verified by the result of the correlation between the cookability and the soil physical and chemical properties as the cookability was positively correlated to the clay content $(\mathrm{r}=0.89)$; the silt content $(\mathrm{r}=0.87)$; the saturation $(r=0.81)$; the organic carbon $(r=0.89)$; and the cation exchange capacity $(\mathrm{r}=0.73)$ (Table 2$)$.

These results confirm the general knowledge that faba beans grown in different locations differ in their cooking quality. The same results were also found by Youssef [10], who reported that Giza 1 and Giza 2 varieties grown in two different locations showed marked variation in their cooking quality. Moreover, Halstead and Gfeller [11] reported that the cooking quality of a certain variety of field peas was influenced by the level of soil fertility and the addition of fertilizers ( $\mathrm{P}$ and $\mathrm{K}$ ) in a green house experiment. In addition, Magboul, et. al. [12] stressed that; the nutrient content of a particular type of food can widely vary according to climate, nature of soil, irrigation, fertilizers and variety. In addition to that, Shehata et al. [13] stated that, faba bean grown in the Upper Egypt produced stewed beans which had higher penetrometer readings and hydration coefficients than those grown in 
the Lower Egypt. Latitude was negatively correlated to penetrometer reading and the hydration coefficient of stewed faba beans. In this study, the results showed a highly significant difference among the faba bean lines grown in the various environments. The two lines; Triple White and C.86 presented the highest cookability for the three seasons and the lowest cookability was reported by the line Z B F.1/1 in the three seasons (Table 2, Table 3). These results were confirmed by Youssef [10] who reported that, samples belonging to each variety and grown in different location appreciably vary in their cooking quality. On the other hand, according to Gfeller and Halestead [14], the inheritance of good cooking quality of peas appeared to be controlled by two recessive genes, although there was some indication of a gene-environment interaction. Moreover, water absorption by the cotyledon appears to be the key property that affects the cookability of legumes [15]. Furthermore, it is not clear which morphological components of the seed that are responsible for differences in water absorption among cultivars and seeds of the same cultivar. faba beans with different degrees of cookability varied in seed coat microstructure. Some aspects of the microstructure control the rate of water penetration into the cotyledon during all stages of cooking. Those aspects could be related to the cookability. Difference in the cookability among varieties grown in the same or in diverse production areas may be caused by seed microstructure differences that regulate water penetration and movement within the seed [16]. In addition, cookability may also be controlled by intrinsic properties of the cotyledon components and the cotyledon structure [17]. In this study it seems that pod position played a considerable role in the quality of faba bean as the lower nodes recorded the highest cookability percentage of 31.4 and 29.5 in the second and the third seasons respectively (Table 2, Table 3). The results obtained showed highly significant interaction between lines and environments. These may be related to genetic inheritance and environment. These finding were confirmed by the report of Annicchiarico and Iannucci [18] who studied 17 faba bean cultivars belonging to four germplasm types; Mediterranean, semi-Mediterranean, winter, and spring grown in two climatically contrasting sites for two years per site and two sowing times per year. Their results showed that, the genotype $\mathrm{x}$ environment interaction was large and was mainly due to the geo climatic area and the germplasm type. Adaptation to each site was related to different and partly incompatible traits, mainly related to site-specific optima of earliness of cycle and stress tolerance. The results supported the specific breeding for each geo climatic area based on distinct genetic bases and selection environments. Furthermore, cookability was positively correlated to the clay and silt contents and negatively to the sand portion (Table 4). These results confirm the earliest findings of Shehata et al. [13] as particle size categories (i.e. clay, silt and sand) were found to be correlated to the softness score the penetrometer readings. The clay and silt contents were positively correlated, while the sand fraction was negatively correlated to the cooking characteristics. On the basis of cookability studies of legumes, many research studies concluded that, the cookability of legumes depends on genetic factors, physical properties, chemical composition, seed structure, processing and storage. However, prolonged cooking reduces the nutritive value of beans due to the destruction or inactivation of certain essential amino acids [19].

Table 2. Effect of environment, line, pod position and their interaction on cookability (\%) of faba bean grown during season $2006 / 2007$

\begin{tabular}{|c|c|c|c|c|c|c|c|c|c|c|c|c|c|c|c|c|c|c|c|}
\hline \multirow{3}{*}{ Environment } & \multicolumn{18}{|c|}{ Lines } & \multirow{3}{*}{ Envi mean } \\
\hline & \multicolumn{3}{|c|}{ H.72/7/ 1} & \multicolumn{3}{|c|}{ Daba.1/ 1} & \multicolumn{3}{|c|}{ Z B F.1/ 1} & \multicolumn{3}{|c|}{ C.86 } & \multicolumn{3}{|c|}{ Turki } & \multicolumn{3}{|c|}{ T.W } & \\
\hline & $\mathrm{L}$ & $\mathrm{U}$ & $\mathrm{B}$ & $\mathrm{L}$ & $\mathrm{U}$ & $\mathrm{B}$ & $\mathrm{L}$ & $\mathrm{U}$ & $\mathrm{B}$ & $\mathrm{L}$ & $\mathrm{U}$ & $\mathrm{B}$ & $\mathrm{L}$ & $\mathrm{U}$ & $\mathrm{B}$ & $\mathrm{L}$ & $\mathrm{U}$ & $\mathrm{B}$ & \\
\hline$E_{1}$ & 36 & 29 & 32 & 35 & 31 & 32 & 32 & 23 & 30 & 47 & 36 & 42 & 36 & 30 & 34 & 44 & 35 & 38 & 35 \\
\hline $\mathrm{E}_{2}$ & 33 & 25 & 26 & 33 & 26 & 31 & 29 & 21 & 27 & 40 & 34 & 38 & 32 & 29 & 32 & 42 & 31 & 35 & 31 \\
\hline $\mathrm{E}_{3}$ & 27 & 24 & 25 & 27 & 23 & 25 & 24 & 19 & 22 & 30 & 25 & 28 & 28 & 20 & 25 & 34 & 26 & 30 & 26 \\
\hline$E_{4}$ & 30 & 26 & 29 & 32 & 25 & 28 & 27 & 23 & 25 & 31 & 24 & 28 & 34 & 26 & 31 & 37 & 31 & 35 & 29 \\
\hline $\mathrm{E}_{5}$ & 22 & 19 & 20 & 24 & 18 & 21 & 19 & 13 & 17 & 25 & 20 & 22 & 24 & 16 & 20 & 29 & 23 & 26 & 21 \\
\hline Mean & 30 & 25 & 27 & 30 & 25 & 28 & 26 & 20 & 24 & 35 & 28 & 32 & 31 & 24 & 29 & 37 & 29 & 33 & \\
\hline $\mathrm{SE}$ & & & nvi & men & $\begin{array}{l}=0.3 \\
\text { ine * }\end{array}$ & $\begin{array}{l}{ }^{*}, \mathrm{~L} \\
\mathrm{de}\end{array}$ & $\begin{array}{c}\mathrm{e} \pm 0 \\
0.71\end{array}$ & $\begin{array}{l}1^{* * * *} \\
\mathrm{~s}, \mathrm{El}\end{array}$ & $\begin{array}{l}\text { ode } \\
\text { ont }\end{array}$ & $\begin{array}{l}0.29 \\
\mathrm{nt} *\end{array}$ & ine ${ }^{*}$ En & $\begin{array}{l}\text { onn } \\
\text { de }\end{array}$ & $\begin{array}{l}\text { At } * I \\
1.58\end{array}$ & $\mathrm{e} \pm$ & $11^{* *}$ & & & & \\
\hline $\mathrm{CV} \%$ & & & & & & & & & 7.9 & & & & & & & & & & \\
\hline
\end{tabular}

$* *$ and $* * *=$ Significant at $1 \%$ and $0.1 \%$ probability level, respectively, NS $=$ Not significant.

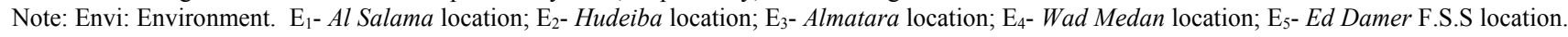
L: lower node; U: upper node; B: bulk node.

Table 3. Effect of environment, line, pod position and their interaction on cookability (\%) of faba bean grown during season $2007 / 2008$

\begin{tabular}{|c|c|c|c|c|c|c|c|c|c|c|c|c|c|c|c|c|c|c|c|}
\hline \multirow{3}{*}{ Envi } & \multicolumn{18}{|c|}{ Lines } & \multirow{3}{*}{ Envi mean } \\
\hline & \multicolumn{3}{|c|}{ H.72/ 7/ 1} & \multicolumn{3}{|c|}{ Daba.1/ 1} & \multicolumn{3}{|c|}{ Z B F.1/ 1} & \multicolumn{3}{|c|}{ C. 86} & \multicolumn{3}{|c|}{ Turki } & \multicolumn{3}{|c|}{ T.W } & \\
\hline & $\mathrm{L}$ & $\mathrm{U}$ & B & $\mathrm{L}$ & $\mathrm{U}$ & $\mathrm{B}$ & $\mathrm{L}$ & $\mathrm{U}$ & $\mathrm{B}$ & $\mathrm{L}$ & $\mathrm{U}$ & $\mathrm{B}$ & $\mathrm{L}$ & $\mathrm{U}$ & $\mathrm{B}$ & $\mathrm{L}$ & $\mathrm{U}$ & $\mathrm{B}$ & \\
\hline$E_{1}$ & 34 & 23 & 29 & 35 & 25 & 32 & 35 & 25 & 32 & 44 & 33 & 36 & 42 & 26 & 35 & 43 & 36 & 38 & 33 \\
\hline$E_{2}$ & 29 & 23 & 27 & 32 & 27 & 33 & 29 & 19 & 26 & 35 & 30 & 31 & 28 & 22 & 25 & 51 & 28 & 39 & 30 \\
\hline$E_{3}$ & 25 & 18 & 22 & 24 & 19 & 20 & 22 & 14 & 18 & 28 & 15 & 24 & 21 & 16 & 17 & 34 & 23 & 28 & 22 \\
\hline $\mathrm{E}_{4}$ & 27 & 18 & 23 & 27 & 18 & 22 & 24 & 16 & 17 & 31 & 28 & 30 & 29 & 18 & 24 & 35 & 28 & 31 & 25 \\
\hline $\mathrm{E}_{5}$ & 23 & 15 & 19 & 15 & 11 & 14 & 15 & 11 & 13 & 23 & 17 & 17 & 23 & 19 & 21 & 22 & 17 & 19 & 18 \\
\hline Mean & 27 & 19 & 24 & 27 & 20 & 24 & 25 & 17 & 21 & 32 & 25 & 28 & 29 & 20 & 25 & 37 & 26 & 31 & \\
\hline SE & & & & nme & $\begin{array}{l} \pm 0 . \\
\text { Line }\end{array}$ & *** & $\begin{array}{r}\text { ne } \pm \\
=0.7\end{array}$ & $\begin{array}{l}41^{* *} \\
\text { IS }, E\end{array}$ & $\begin{array}{l}\text { Node } \\
\text { iron }\end{array}$ & $\begin{array}{c}0.29 \\
\mathrm{nt} *\end{array}$ & $\begin{array}{l}\text { En } \\
e^{*}\end{array}$ & onm & $\begin{array}{c}* \mathrm{~L} \\
58 \mathrm{NS}\end{array}$ & \pm 0 & & & & & \\
\hline $\mathrm{CV} \%$ & & & & & & & & & 8.8 & & & & & & & & & & \\
\hline
\end{tabular}

$* *$ and $* * *=$ Significant at $1 \%$ and $0.1 \%$ probability level, respectively, NS $=$ Not significant.

Note: Envi: Environment. $\mathrm{E}_{1}-$ Al Salama location; $\mathrm{E}_{2}-$ Hudeiba location; $\mathrm{E}_{3}$ - Almatara location; $\mathrm{E}_{4}-$ Wad Medan location; E $5_{5}$ Ed Damer F.S.S location.

L: lower node; U: upper node; B: bulk node. 
Table 4. Correlation coefficients between soil (physical and chemical) properties and cookability \% of various lines of faba bean grown in different environments ${ }^{b}$

\begin{tabular}{|c|c|c|c|c|c|c|c|c|c|c|c|}
\hline $\begin{array}{c}\text { Soil depth } \\
(\mathrm{cm})\end{array}$ & Clay \% & Silt \% & Sand \% & Sat \% & $\begin{array}{c}\mathrm{pH} \\
\text { paste }\end{array}$ & $\begin{array}{c}\text { E.C } \\
(\mathrm{dS} / \mathrm{m})\end{array}$ & O.C \% & $\begin{array}{c}\text { CEC } \\
\text { Cmol+/kg }\end{array}$ & SAR & $\begin{array}{c}\text { Available. P } \\
(\mathrm{mg} / \mathrm{kg} \text { soil })\end{array}$ \\
\hline $0-15$ & 0.85 & 0.95 & -0.96 & 0.79 & -0.96 & -0.81 & 0.73 & 0.60 & 0.16 & 0.69 \\
\hline $15-30$ & 0.89 & 0.84 & -0.92 & 0.81 & -0.59 & -0.88 & 0.94 & 0.76 & -0.28 & -0.34 & 0.46 \\
\hline $30-45$ & 0.84 & 0.78 & -0.96 & 0.89 & -0.24 & -0.82 & 0.26 & 0.77 & -0.74 & -0.61 & 0.31 \\
\hline $45-60$ & 0.92 & 0.89 & -0.91 & 0.56 & -0.52 & -0.81 & 0.87 & 0.67 & -0.73 & -0.56 & 0.35 \\
\hline Mean & 0.89 & 0.87 & -0.94 & 0.81 & -0.65 & -0.82 & 0.89 & 0.73 & -0.70 & -0.51 & 0.26 \\
\hline
\end{tabular}

a lines:1- H.72/ 7/ 1; 2- Daba.1/ 1; 3- Z B F.1/ 1; 4- C.86; 5- Turki; 6- T. W

b Environment: $\mathrm{E}_{1}-$ Al Salama location; $\mathrm{E}_{2}-$ Hudeiba location; $\mathrm{E}_{3}-$ Almatara location; $\mathrm{E}_{4}-$ Wad Medan location; $\mathrm{E}_{5}-$ Ed Damer F.S.S location.

Sat: saturation; E.C: electrical conductivity; O.C: organic carbon; CEC: cation exchange capacity; SAR: sodium adsorption ratio; ESP: exchangeable sodium percentage; Avail P: available Phosphorus.

\section{Conclusion}

The results obtained from this study, that the faba bean seeds cookability varied at the different environments and with different pod position from bottom to top. The lower pods showed the highest cookability. Further research is needed in future to cover a wide range of environments and verities to improve the quality of faba bean crops.

\section{References}

[1] Abdalla, A. A., Ahmed, M. F. Taha, M. B. and El Naim, A.M. (2015). Effects of Different environments on yield components of Faba Bean (Vicia faba L.). International Journal of Agriculture and Forestry. 5(1): 1-9.

[2] Hawatin, G. and Stewart, R. (1979). The development, production and problems of faba bean (Vicia faba L.) in West Asia and North Africa. FABIS Newsletter. 1, 7-9.

[3] Picard, J. J., Bond, D. A., Monti, L. and Steuckardt, R. (1988). Production of pea, faba bean and chickpea in Europe, Pp. 10651080. in: R.J. Summerfield (ed.). World Crops: cool season food legumes Kluwer Publishers, Dordrecht, the Netherlands.

[4] FAO. (2012). Statistical Yearbook. World food and Agriculture, Rome, Italiy.

[5] Askar, A. (1986). Faba beans (Vicia faba L.) and their role in the human diet. Fd. sci. Pres. Fd. Nutr Bulletin 8 (3).

[6] Clarke, H. E. (1970). Evaluation of Vicia faba (Broad Bean) in Animal Nutrition. Proc. Nutr. Soc. 29, 64 -79.

[7] Eden, A. A. 1968 A Survey of the Analytical Composition of Field Beans (Vicia faba). J. Agri. Sci. 70, 229-301.

[8] Salih, S. H. (1996). Faba bean research in the Sudan. In Rehabilitation of faba bean. Wolfgane B. and Sadiki, M. (eds)
ACTEs pub. 24 August -27 may, Al Rabat.

[9] Elsheikh EAE, Elzidany AA. 1997. Effect of Rhizobium inoculation, organic and chemical fertilizers on proximate composition, in vitro protein digestibility (IVPD), tannin and sulphur content of faba beans. Food Chem 59: 41-45.

[10] Youssef, M. M. (1978). Astudy of facters affecting the cookability of faba beans (Vicia faba L.) Ph. D. Thesis, College of Agriculture, Univ. of Alexanderia, Egypt.

[11] Halstead, R. L. and Gfeller, F. (1964). The cooking quality of field peas Can. J. Plant. Sci. 44, 221-228.

[12] Magboul, B. L., Youssef, K.M. and Khattab, A.H. (1976). A not on chemical composition of broad bean, haricot beans and cotton seed. Sudan J. Fd. Sci. Technol. 8 (1), 85-88.

[13] Shehata, A. M. El-Tabey, Youssef, M. M., El-Rouby, M. M., Mesallam, A. S., El-Banna, A. and El-Shimy, H. (1981). Relationship between cooking characteristics of faba bean and agronomical variables (proposal review).

[14] Gfeller, F. and Halstead, R.L. (1967). Selection for cooking quality in field peas. Can. J. Plant Sci., 47: 631-634.

[15] Sefa-Dedeh, S., Stanley, D. W., and Voisey, P. W. (1979 a). Effect of storage time and conditions on the hard -to-cook defect in cowpeas (Vigna unguiculata). J. Food Sci. 44,790

[16] Youssef, M. M. and Bushuk, W. 1984. Microstructure of the seed coat of faba bean (Vicia faba L ) seeds of different cookability. American Association of Cereal Chemists, Inc. 61 (4), 381-383.

[17] Youssef, M. M., Bushuk, W., Murray, E. D., Zillman, R. and El-Tabey Shehata, A. M. (1982). Relationship between Cookability and Some Chemical and Physical Properties of Faba Beans (Vicia faba L.). J. Food Sci. 47, 1695-1709.

[18] Annicchiarico, P. and Iannucci, A. (2008). Breeding strategy for faba bean in Southern Europe based on cultivar responses across climatically contrasting environments. Crop Sci. 48 (3), 983-991.

[19] John, S., Arunasalam, K. Yeung, D. Kakuda, Y. and Mittal, G. (2004). Phytate from edible beans: Chemistry, processing and health benefits. Food, Agri and Envi. 2 (1), 49-58. 